\title{
How do mid-senior multinational officers perceive shared leadership for military teams? A qualitative study
}

\author{
Sultan Serkan Cakiroglu \\ ISCTE-Instituto Universitario de Lisboa, Lisbon, Portugal
}

António Caetano

Applied Psychology Research Center Capabilities and Inclusion (APPsyCI), ISPA, Lisboa, Portugal and ISCTE-Instituto Universitario de Lisboa, Lisbon, Portugal, and Patrícia Costa
ISCTE-Instituto Universitario de Lisboa, Lisbon, Portugal

\begin{abstract}
Purpose - The purpose of this study is to explore the military team members' (mid-senior multinational officers') perceptions of shared leadership and analyze the facilitation of shared leadership in military teams.

Design/methodology/approach - The sample size was 20 interviewees that participants must hold leadership positions at the mid-senior management level and from NATO member countries. To analyze the data, the authors used Gioia's thematic analysis methodology (Gioia et al., 2013) and manual coding rather than computer usage for the analysis, due to the small data pool and their proficiency in literature.

Findings - Complexity and the new information era force military organizations toward the change and that with shared leadership they can even change the organization's culture. The final framework highlights five main dimensions that emerged from mid-multinational military officers' experience: driving forces of change, triggers to shared leadership, specific cases shared leadership, operational team environment and operational team characteristics. Results of the study supported that driving forces of change comprised the primary factor affecting shared leadership in military project teams.

Practical implications - The Headquarter environment (strategic and operational planning) and planning were critical factors for the successful implementation and development of shared leadership in military project teams. Thus, military organizations could easily implement the shared leadership approach in the military research teams and planning teams.
\end{abstract}

Originality/value - The authors present a framework of leadership change context for military teams, which depicts how shared leadership could be implemented differently in military teams.

Keywords Effectiveness, Shared leadership, Military teams, Operational teams, Project teams

Paper type Research paper

\section{Introduction}

The military environment is more complex than ever; each year the military field grows with the range of weapons, and the amount of equipment used is increasing. The military playfield is greater than it has been for many years. Besides that, the military environment has changed dramatically as technological capabilities have grown in all spheres. One of the greatest challenges that leaders face today is the need to position and enable organizations

Received 13 November 2019 Revised 22 April 2020 Accepted 30 April 2020 military teams
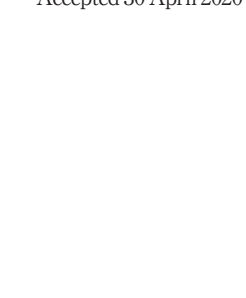
and people to adapt in the face of increasingly dynamic and demanding environments (UhlBien and Arena, 2018; Sweeney et al., 2019). Alarmingly, emerging challenges, such as the rise of a new generation of communications technology, unmanned ground vehicles and Artificial intelligence (AI), have caused the military environment to become more complex and prolonged, involving more states, non-states, private and hybrid actors. While the environment and equipment are changing, what about the leadership? Is traditional leadership in this context meeting new requirements and adapting to change?

Military organizations are experiencing fast-changing environments marked by increasing complexity and ambiguity, like the business world, which requires new management strategies for traditional organizational structures that depend on vertical leadership. This new "volatile, uncertain, complex, and ambiguous" situation is described as the VUCA world in Kennedy's (2017) study. According to Johansen and Voto (2014), the terminology was first coined at the USA's Army War College, and today's leaders face the challenge of identifying the ideal leadership style with which to meet conditional needs Asymmetric conflict, technological change, and challenges related to organizational design challenge today's militaries and have dramatically impacted on military decision-making and behavior. Shared leadership theory is rising as a style that potentially fits the demands of this new complex environment (Pearce and Conger, 2003; Kocolowski, 2010; Pearce et al., 2018; Müller et al., 2018; Wu et al., 2020). It is clear that no single leader can handle the complexity of such an environment. There is no doubt that a leader cannot lift the entire heavy workload by him/her. She/he needs help with this dense, complex workload. Support comes from team members. In the face of complexity and other, increasingly severe, team effectiveness problems, it is evident that military organizations need sustainable solutions to respond to such global challenges. Like ships in the navy, most of the tools and systems used in the military have been growing more complex every day and getting more difficult for both leaders and team members to integrate. Therefore, is it still a challenge for military organizations to handle increasing complexity? Shared leadership may be a practical solution to complex problems. Shared leadership, in which team members' objective is to lead one another toward the achievement of collective goals (Pearce et al., 2009b), facilitates increased teamwork outputs; in addition to which considerable scientific research indicates that shared leadership positively affects organizational outcomes (D'Innocenzo et al., 2016; Wang et al., 2014). This implies that leaders can create an environment of shared leadership to enable better decision-making processes (Kocolowski, 2010; Pearce et al., 2009b).

While business and war are often thought of as two separate and distinct activities, analogies abound to the effect that business is akin to war and war is akin to business. The classic military theorists Sun-Tzu and Clausewitz (2000) both described how organizational issues resemble military strategy (Augier et al., 2014). Shared leadership is highly practical in healthcare organizations and public universities, whereas we find a scarcity of discussion on the implementation of shared leadership in military organizations. Shared leadership is an emerging style in organization studies. How can these expectations fit the demands of military organizations? Can shared leadership be implemented in military organizations? Do we have to change traditional leadership into shared leadership as a result of changes in the military field? Is there a way to combine these leadership styles? A more serious attempt at analysis is needed, given the fact that our traditional models of leadership must change in an age of teamwork and knowledge work (Drucker, 2001; Pearce and Sims, 2002; Pearce, 2004; Day et al., 2004; Osborn and Hunt, 2007; Costa et al., 2017; Shondrick et al., 2010; Yukl, 2013).

One can argue that the traditional concepts of leadership can no longer accommodate the changing nature of the work environment and the expectations of new generations, which make it more difficult for leaders to possess all the expertise required to perform the 
required leadership functions adequately (Groon, 2002; Howe and Strauss, 2003; Pearce, 2004; Hiller et al., 2006; Pearce et al., 2009a; Friedrich et al., 2009; Wang et al., 2014). As a traditional leadership, vertical leadership models use centralizing power and influence utilized through a hierarchical leader (Pearce et al., 2009b). On the other side, shared leadership utilizes decentralization, power sharing and influence among peers to achieve effectiveness (Pearce et al., 2008). Moreover, as teams have increasingly become the main building blocks of organizations (Mathieu et al., 2014), scholars have begun to research leadership at the team level of analysis, investigating the role of team leaders in creating, developing, and promoting team effectiveness (Mathieu et al., 2008). Though some researches into the relation of shared leadership and effectiveness are positive in conventional contexts (Carson et al., 2007; Ensley et al., 2006), scholars have yet to examine shared leadership in military organizations. Shared leadership may reveal the members' knowledge and abilities on the surface, but in military conditions of total stress within a strict hierarchy, members must nearly always hide their knowledge in their minds, as it is difficult to present their skills and abilities on the table. Shared leadership may change the stressful job climate surrounding military teams, potentially activating their problemsolving abilities and releasing their real potential to develop into high-performing teams, so that together, they can generate sustainable solutions to complex issues. Moreover, there are few articles that have scrutinized the relation of shared leadership that influences team types, and military organizations. This investigation addresses the phenomenon of shared leadership implementation in military teams through a qualitative study. To do so, we identify shared leadership for military organizations. First, at the heart of this exploration are stories that reveal the challenge of leading change in military leadership from the leader's perspective, creating an opportunity to explore military experts' values and military contexts. Second, one of our objectives is to understand the team context (military project teams or military operational teams) in which shared leadership might be more viable. Finally, this study focuses on the lived experiences of mid-international officers by exploring and describing their perceptions regarding the development and implementation of shared leadership for the military team types. The interest underlying the study was in uncovering insights into how shared leadership implementation is manifested in military teams with a model that includes the combination of the vertical and shared leadership which Kozlowski and Bell (2003) maintained would be stimulating for military organizations.

This study meets the calls for a qualitative research of shared leadership practice in a different organizational context (Ramthun and Matkin (2014; Sweeney et al., 2019) and examines the perceptions of shared leadership with a sample from nine different countries, with different culture and environment.

\section{Theoretical background}

The core ideas of shared leadership can be traced to earlier studies such as those of Follett (1924), presenting the theory that individuals should follow the person who has essential knowledge pertaining to the particular situation, and Gibb (1954), proposing that tasks must be performed by the group. McGregor's Theory Y, which allows employees to take part in decision-making, is also related to shared leadership (Pearce and Conger, 2003; Nicolaides et al., 2014; Ensley et al., 2006). Shared leadership in teams has already been examined by researchers (Pearce and Sims, 2002; Pearce and Conger, 2003; Yukl, 2013; Hoch and Kozlowski, 2014; Wang et al., 2014; Pearce et al., 2014) over the past two decades. Moreover, the shift to shared leadership has accompanied the rise in cross-functional teams, along with the availability of information and the complexity of larger jobs within nursing, medicine, psychology, business, management and other areas of social science (Bolden, 2011). Although definitions vary 
slightly, shared leadership, distributed leadership, collective leadership, co-leadership, team leadership, informal leadership, pluralistic leadership, emergent leadership and peer leadership have all been advanced as ways to conceptualize and understand how leadership may emanate from, and be shared by, team members (Morgeson et al., 2010; Nicolaides et al., 2014; Pearce et al., 2014). These theoretically overlapping leadership constructs and shared leadership were compared by Zhu et al.'s (2018) in their studies and have in common the fact that this approach distributes the leadership across many, not being exclusive of a few.

One of the recurring problems in the study of leadership is, according to Bass and Avolio (1993), and Pearce and Sims (2002), that there is a tendency to avoid previously existing theories in order to introduce a "new way of thinking." However, shared leadership is a vital departure from vertical leadership, especially for the military organizations. The focal point of shared leadership is the interaction of team members in order to lead collectively, by sharing leadership tasks, rather than having one single individual in the role of the leader. According to Drath (1998), shared leadership is not about the characteristics of the member; indeed, it is about having the entire team, group, or organization participates in the process. In its contemporary form, the perspective that leadership is somehow shared by team members has become known as shared leadership (Nicolaides et al., 2014).

Shared leadership arises when team members actively and intentionally shift the role of leader to one another as necessitated by the environment or circumstances in which the group operates. With shared leadership, the role of leadership does not rest in one person's hands, but rather in the group's hands as they move together toward common objectives (Pearce et al., 2009a, 2009b).

\section{Methodology}

\section{Participants}

The scope of this study was limited to North Atlantic Treaty Organization (NATO) members. The sample size was 20 interviewees. The targeted sample criteria were that participants must hold leadership positions at the mid-senior management level and with the rank of Captain and Lt (2), LCDR and Major (6), CDR and Lieutenant Colonel (10), and CAPT and Colonel (2). The participants were from NATO member countries including Canada (1), Greece (1), Italy (2), Poland (1), Portugal (2), Spain (1), Turkey (9), the UK (1) and the USA (2) and all participants in this qualitative study were male. In purposive sampling for qualitative research, it is essential that the selected target population be able to provide the information most relevant to the study, and selecting a sample with the widest grasp is also important (Merriam and Grenier, 2019). The NATO members were selected because:

- access to these military leaders was granted more readily, as the first author was a member;

- it was a large-scale international military organization, allowing for an appropriate sample to be studied; and

- NATO members have a similar military team approach based on 71 years of standardization exercises.

\section{Instrument}

Collecting first-hand statements of personal experiences gives a researcher the opportunity to capture the subject's meaning in his or her own words (Merriam and Grenier, 2019). In this study, we used an electronic interview for which mid-international officer participants were contacted by email. Electronic interviews are research instruments that use electronic 
communication to access and communicate with participants. The interview questions were constructed around three main areas:

(1) Introductory questions about the participants' approach to shared leadership and vertical leadership in military teams (e.g. What do you think about traditional models (vertical leadership) of military leadership style?).

(2) Conditions of shared leadership for military teams (e.g. Do you think shared leadership has a place in the modern military team contexts? Why or why not? Please provide and describe examples).

(3) Shared leadership perceptions on matters such as team performance criteria for project teams and operational teams (e.g. What will be the positive/negative consequences if shared leadership should be implemented within military organizations in Project team contexts? Please provide and describe examples).

\section{Data analysis}

To analyze the data, we used Creswell's $(2003,2014)$ exploratory research methodology and Gioia's thematic analysis methodology (Gioia et al., 1994; Corley and Gioia, 2004; Clark et al., 2010; Gioia et al., 2013). Qualitative methodology has been used before to study leadership in a military context. For example, Lindsay et al. (2011) examined shared leadership relation in the Army and Air Force leadership doctrine, whereas Ramthun and Matkin (2014) investigated shared leadership with a qualitative case study during extreme situations for US military personnel operating teams.

Qualitative research approaches provide proper methods for exploring the nature of a phenomenon with relatively little information, and are interested in how people interpret their experiences (Hatch, 2002; Merriam and Tisdell, 2015). A qualitative thematic analysis design was appropriate for this study because it seeks to explore and understand the issue of shared leadership by considering factors that help shape that phenomenon (Creswell, 2003).

Adhering to Creswell's $(2003,2014)$ method of thematic analysis, we coded participants as 1-20 instead of by their actual names. We decided on manual coding rather than computer usage for the analysis, due to the small data pool and our proficiency in literature. The Word documents were read and re-read to familiarize ourselves with the data and begin to identify meaningful text and common themes. Sorting the relevant themes in the data generated the First-order themes. These first-order categories constitute the second order themes. Again, we used constant comparison techniques in discerning second-order themes that subsumed the first-order categories (Glaser et al., 1968; Corley and Gioia, 2004). Second-order themes were then assembled to aggregate dimensions. This process involved the relatively straightforward task of examining the relationships among first-order categories and second-order themes that could be distilled into a set of more simplified, complementary groupings. Ultimately, we consolidated the themes into more general dimensions of analysis. In our analysis, we generated the first-order categories from the interviews and these relevant categories constitute our 15 second-order themes. Additionally, we assembled our 15 second-order themes into five aggregate dimensions.

\section{Results}

The final data structure is illustrated in Figure 1, which summarizes the second-order themes and aggregations that led us to the development of a model of the military leadership change process. Three dimensions belong to perceptions related to the military Project teams (Driving forces of Change, Triggers to SL, Specific Cases SL for Military Teams) and 
TPM

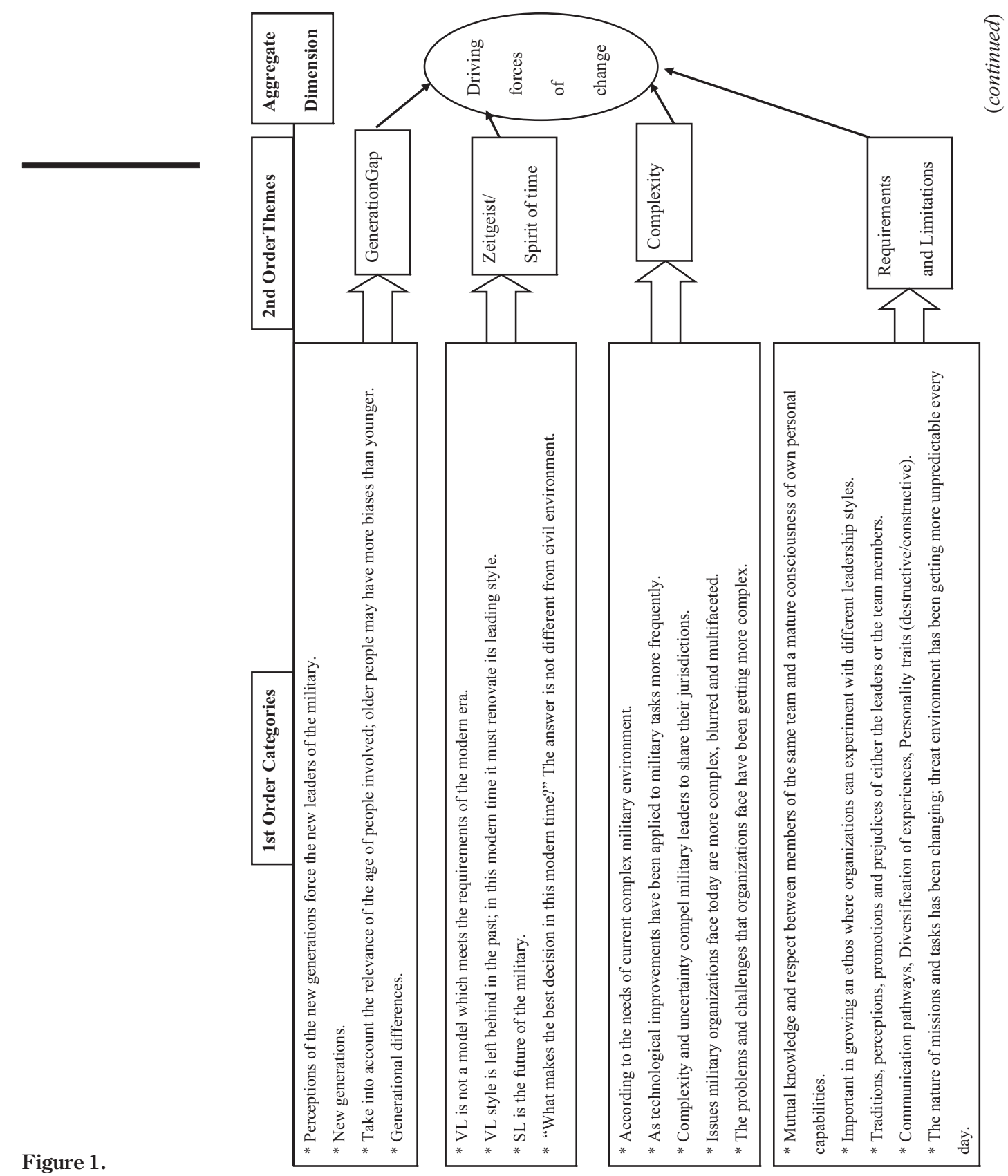

Data structure 

TPM

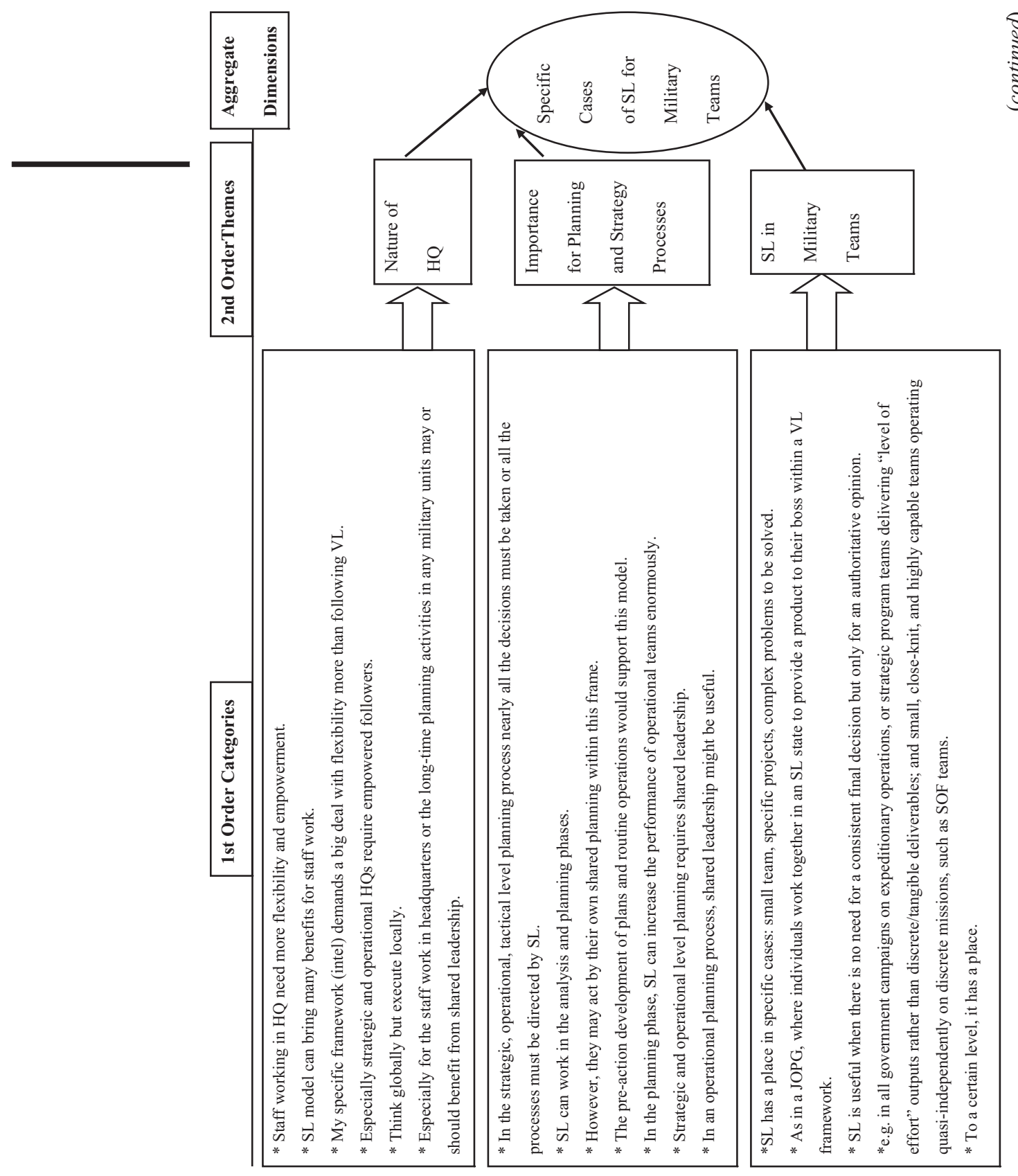

Figure 1. 


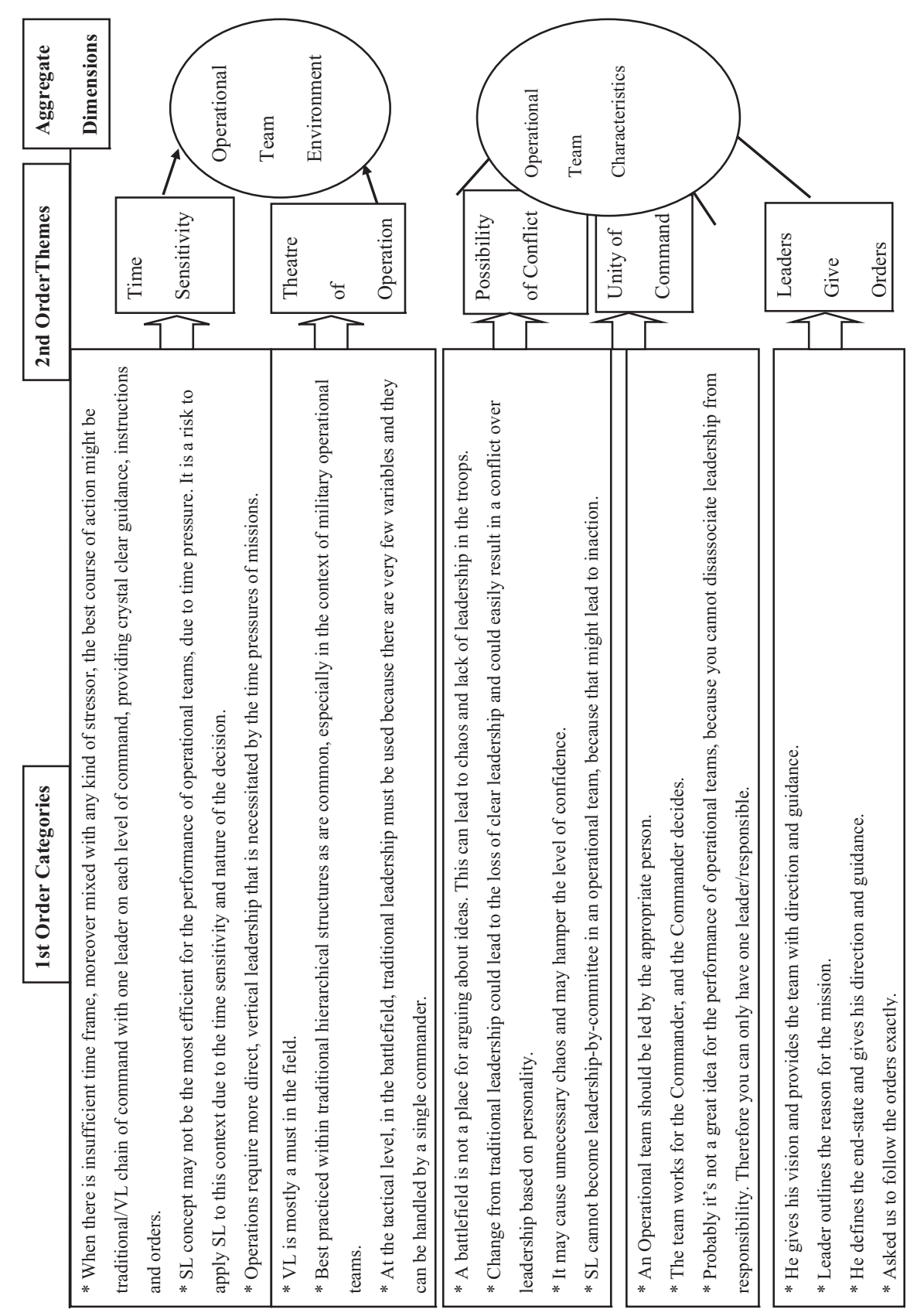

leadership for military teams

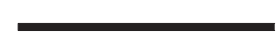


two aggregate dimensions to the perceptions related to the military Operational teams: Operational Team Environment, and Operational Team Characteristics.

\section{Military project teams}

A sub-theme that emerged from the data was that participants believed that shared leadership could be implemented for the military Project teams ("In a Project team in which shared leadership is implemented, the duty can be finished in a shorter time and more efficiently", Participant 4). It will facilitate collaborative efforts and enable members to share leadership effectively ("The advantages are numerous - from increased ownership and buyin to the ability to account for team weaknesses or individual lack of depth of knowledge/ experiences through collective discussion, a more comprehensive product should be expected", Participant 17). The first aggregate dimension induced from the themes is the Driving forces of Change that impel military teams toward shared leadership.

\section{Driving forces of change}

Driving forces of change were perceived as a reason why shared leadership must be implemented for military project teams. Four specific themes relating to the origins of shared leadership implementation in military project teams characterized our participants' experiences:

- generation gap;

- zeitgeist/spirit of time;

- complexity; and

- requirements and limitations.

Participants identified many factors that justify a change in the way leadership happens in the military context. On the one hand, they speak of different expectations on the part of new generations ("And mostly the evolved perception of the new generations force the new leaders of the military to have SL in the modern military contexts", Participant 1), noting that these new individuals may have a role in implementing shared leadership, by contrast with their older counterparts ("because older people may have more biases than younger", Participant 9). In relation to the generation gap, participants also mentioned modern time needs, besides which they particularly emphasized technology and IT upgrading as factors that create the complexity ("however, nowadays because of the technological developments, information pollution", Participant 1). They overwhelmingly explained that this complexity and the new information era required change and that with shared leadership they could even change the organizational culture ("The ability of individuals to work together, critically their willingness to accept criticism and change their views and culture if necessary", Participant 7).

\section{Triggers to shared leadership}

Triggers to Shared Leadership were perceived as key in making this kind of leadership effective for military project teams. Three specific themes related to the origins of shared leadership implementation in military project teams characterized our participants' experiences:

- pros of collective IQ;

- $\quad$ specialization/K.S.A.; and

- inappropriateness of vertical leaders. 
Participants identified the military team's situation as triggering shared leadership, even sometimes forcing military project teams to adopt it. They brought out the great value of the collective product and IQ ("I think that shared leadership can help project teams because each person's strengths can help provide a better product to the team's collective product", Participant 7) for mitigating the incompetence of the single leader ("No single leader will have all the answers or even be able to make sense of the more significant challenges that are encountered", Participant 13). Participants noted the single leader's ineffectiveness in dealing with the problems, due to the wide area of specialization. They also described shared leadership as inescapable because of the specialization in military project teams ("Shared leadership is a leadership style where there are several leaders who manage different areas of the projects and who must be guided by guidelines previously defined by consensus of the leaders themselves", Participant 8). Moreover, all the participants explained the disadvantages of vertical leadership ("Vertical leadership is vulnerable to the bias of the leader and can be very personality driven - capable of either elevating or destroying the team", Participant 17) that lead military organizations to adopt shared leadership for military project teams.

\section{Specific cases of shared leadership for military teams}

Specific Cases of Shared Leadership for Military Teams was perceived as key to making shared leadership practicable for military project teams. Three specific themes related to the origins of shared leadership implementation in military project teams characterized our participants' experiences:

- $\quad$ nature of (HQ) environment;

- importance for planning and strategy processes; and

- shared leadership in military teams.

Participants overwhelmingly stated that shared leadership can be implemented for military teams in specific cases where they are working in an office environment, and also during the planning process ("Shared leadership can work in the analysis and planning phases", Participant 10). They stated that headquarters availability generated shared leadership in both aspects, as an office environment and also as a site of strategic/operational planning ("Especially for the staff working in headquarters, or the long-time planning activities in any military units, may or should benefit from the shared leadership", Participant 15), and explained that there were many specific areas which did not deal with direct operations ("My specific framework (intel) demands a big deal with flexibility more than following vertical leadership", Participant 12). These specific areas are extensive for military teams, from the highest teams that decide the command policy ("Shared leadership is useful planning staffs; development of command policy, "planning boards", Participant 17) to the smallest teams ("Shared leadership is useful on scientific type subjects, use of the UAVs out of the battle space", Participant 5) with diverse subjects ("Small unit training events", Participant 17).

\section{Military operational teams}

A major sub-theme that emerged from the data was the belief of participants that shared leadership cannot be implemented in military operational teams during the operation phase. Vertical leadership must prevail for military operational teams. Two aggregated dimensions induced from the themes are the operational team environment and operational team characteristics that impel military teams toward vertical leadership. 
Operational team environment was perceived as key to making vertical leadership indispensable for military operational teams. Two specific themes related to the origins of shared leadership implementation in military project teams characterized our participants' experiences:

(1) time sensitivity; and

(2) theatre of operations.

Participants did not support the shared leadership approach in the operational team environment when the team was operating under time limitations ("Shared leadership may be useful in almost all the contexts. The only exception could be the time-sensitive situations", Participant 9) or during execution in the operational area ("SL is not useful, and even dangerous, in fighting/action units at all levels during execution phases", Participant 10).

\section{Operational team characteristics}

The factor of operational team characteristics was perceived as key to making vertical leadership essential for military operational teams. Three specific themes related to the origins of shared leadership implementation in military project teams characterized our participants' experiences:

- possibility of conflict;

- unity of command; and

- leaders give orders.

Participants explained the contradiction between shared leadership and operational team characteristics. They did not approve of the shared leadership approach in operational teams, as it could cause conflict or even hamper the accomplishment of the mission ("Shared leadership cannot become leadership-by-committee in an operational team, because that might lead to inaction", Participant 7). That conflict would spoil the unity of the command, which they all agree is indispensable for operational teams ("Here, you risk a convoluted chain of command, an inability to communicate direct/concise orders, and the introduction of a potential inadvertent delay in action/execution. Simply put, if an attack is in progress and the decision cycle (of life and death) is reduced to $30 \mathrm{~s}$, a civil discussion on options is not effective to neutralize the risk", Participant 17).

\section{Leadership change context model for military teams}

Aggregate dimensions are the bedrock of the theoretical framework of leadership change context for Military Teams that is presented in Figure 2. Five key dimensions that support this framework depict the implementation of shared leadership and a combination of shared and vertical leadership in military teams.

One participant provided additional insight into this phenomenon from a research perspective:

I think shared leadership will increase the performance of the team members. Shared leadership will help the members of the project team to internalize the decision made by the help of all or at least most of the team members. However, project teams in a military environment are generally composed from different departments of the $\mathrm{HQ}$. So not only shared leadership but also traditional leadership model works in this situation. A mixture of both should be implemented. 


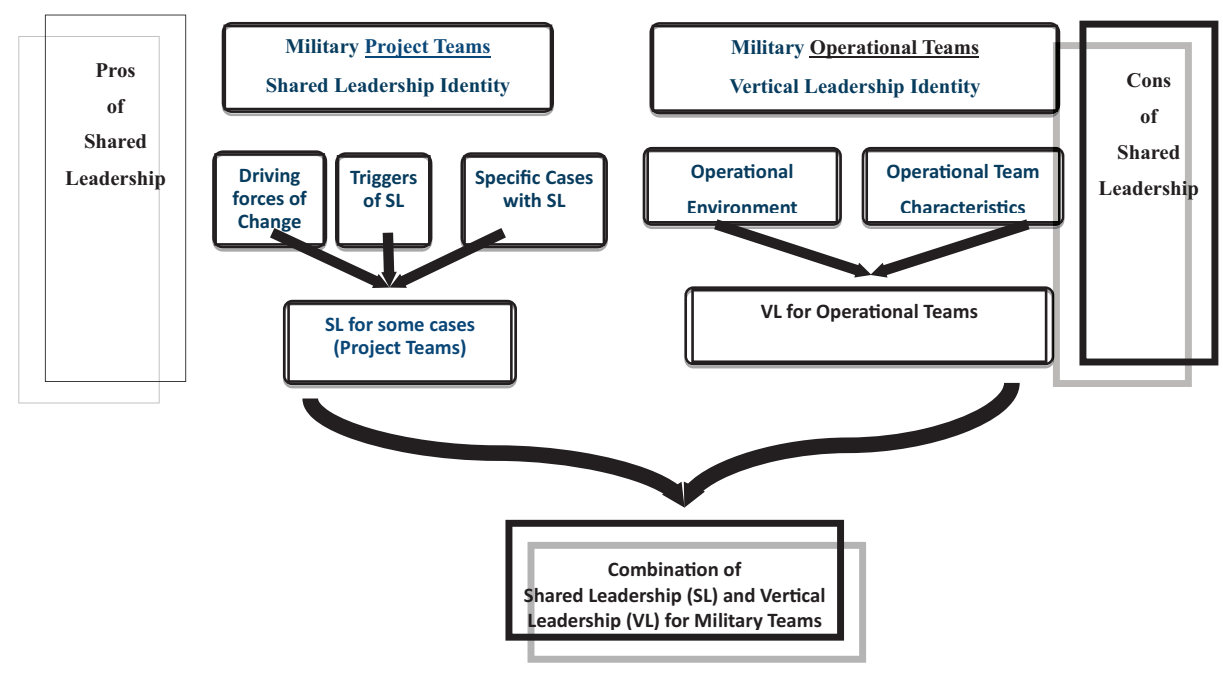

Shared
leadership for
military teams

Another participant explained the combination of shared leadership and vertical leadership as follows:

I believe shared leadership should exist within a traditional leadership framework for reasons stated above, such as the ability for the command or organization to effectively make and implement decisions. If leadership is exclusively shared then the organization may be paralyzed.

\section{Discussion}

The study reveals the development and implementation reasons for shared leadership in military organizations. Driving forces of change constituted the primary factor affecting shared leadership in military project teams, while the operational environment was the most important hindrance to shared leadership in military operational teams. Accordingly, it is essential to consider when and how shared leadership might be most beneficial. A significant sub-theme that emerged from the data was that shared leadership could be implemented for military project teams. There was a consensus that shared leadership would facilitate collaborative efforts and enable them to function effectively for these teams. Our results, namely the benefits of planning with a shared leadership approach for military project teams, confirm Choi et al. (2017) conclusion that shared leadership is positively related to organizing and planning effectiveness. Finally, there was also a consensus that, due to the operational environment and characteristics of the operational team, vertical leadership must remain for operational teams. Participants acknowledged that operating in time-limited situations required vertical leadership. While shared leadership can be suitable in some situations, and it is important to indicate that shared leadership may not always be effective (Sweeney et al., 2019) also as stated in D'Innocenzo et al. (2016), it is indeed not a panacea. Therefore, teams in crisis, with limited time, can fail if leadership is shared between members. In that kind of time-sensitive situation, which characterizes the operational environment most of the time, leadership by a single person was essential for directing others and making a quick decision. On the other hand, how can it be 
correct for military project teams to make rapid decisions? In most cases project teams do not need speed; whereas all the participants support traditional (vertical) leadership due to the field/operational environment. We can easily begin to implement the shared leadership approach in the divisions in headquarters. Participants described how shared leadership exists in military project teams but is dependent on the vertical leader's permission, so that when the division leader/commander wants to use his/her rank, he/she can easily revert to the exercise of authority. However, even in operational teams, shared leadership may be useful in the planning phase. Sometimes if you bypass the change, then accidents or fatal mistakes can teach you that you must change. In civil organizations such as companies, lack of effectiveness mostly means losing money, wasting effort, etc., but in military organizations even in peacetime, ineffectiveness can result in deadly accidents or missions.

This study also revealed a "dynamic flexibility" approach in the participants' perception of shared leadership for military teams. It was both an enabler and inhibitor of military teams, as it facilitated collaboration and communication for military project teams, while in the case of operational teams, on the contrary, it created conflict. To resolve this dynamic flexibility, the model of Leadership Change Context for Military Teams depicts the implementation of shared leadership plus a combination of shared and vertical leadership in military teams. We advocate complementarity of hierarchical leadership and shared leadership as well as the two concepts working in tandem (Wang et al., 2014). The leadership change context for military teams supports this leadership combination.

\section{Contributions and limitations}

Shared leadership will facilitate collaborative efforts and enable them to be effective for military project teams. As military leaders build shared leadership in project teams, we will be able to do better the things we are currently performing in military teams. We could initiate creation of the shared leadership approach in Project teams within international military organizations like NATO. Thus, multicultural organizations are better able to adapt to change and exhibit more organizational flexibility (White, 1999). Project teams with shared leadership are expected to carry out highly complex cognitive tasks efficiently. After shared leadership is implemented in project teams, the output will lead military leaders and researchers to consider transferring the shared leadership approach to operational teams. Also, a combination of shared leadership and vertical leadership could be viable according to the Leadership change context for military teams framework. Finally, this study may help military leaders understand the importance of implementing shared leadership of military teams. Mid-senior officers were interviewed in terms of our military-team definition, and there were no rejections of the definition. We emphasized that validation of the definition of military project teams and military operational teams offers a promising avenue for future research. Also, this study draws attention to the decision-making process and shared leadership with a model of military teams for future studies. Finally, participants were mid-senior officers as younger members are more likely to engage in shared leadership approach (Muethel et al., 2012), future studies may include only cadets and newly graduated officers.

Overall, we offer a framework unique to this type of teams, therefore contributing to the literature not only in the shared leadership domain, but also in the military context. We hope our work opens avenues for future research that will contribute to better understand, implement and facilitate shared leadership in this very specific and important context. 


\section{References}

Augier, M., Knudsen, T. and McNab, R.M. (2014), "Advancing the field of organizations through the study of military organizations", Industrial and Corporate Change, Vol. 23 No. 6, pp. 1417-1444.

Bass, B.M. and Avolio, B.J. (1993), “Transformational leadership: a response to critiques”, in Chemers, M.M. and Ayman, R. (Eds), Leadership Theory and Research: Perspectives and Directions, Academic Press, San Diego, pp. 49-80.

Bolden, R. (2011), "Distributed leadership in organizations: a review of theory and research", International Journal of Management Reviews, Vol. 13 No. 3, pp. 251-269.

Carson, J.B., Tesluk, P.E. and Marrone, J.A. (2007), "Shared leadership in teams: an investigation of antecedent conditions and performance", Academy of Management Journal, Vol. 50 No. 5, pp. 1217-1234.

Choi, S.B., Kim, K. and Kang, S.W. (2017), "Effects of transformational and shared leadership styles on employees' perception of team effectiveness", Social Behavior and Personality: An International Journal, Vol. 45 No. 3, pp. 377-386.

Clark, S.M., Gioia, D.A., Ketchen, D.J., Jr. and Thomas, J.B. (2010), "Transitional identity as a facilitator of organizational identity change during a merger", Administrative Science Quarterly, Vol. 55 No. 3, pp. 397-438.

Corley, K.G. and Gioia, D.A. (2004), "Identity ambiguity and change in the wake of a corporate spin-off", Administrative Science Quarterly, Vol. 49 No. 2, pp. 173-208.

Costa, P.L., Passos, A.M., Bakker, A.B., Romana, R. and Ferrão, C. (2017), "Interactions in engaged work teams: a qualitative study", Team Performance Management: An International Journal, Vol. 23 Nos 5/6, pp. 206-226.

Creswell, J.W. (2003), Research Design: Qualitative, Quantitative, and Mixed Methods Approaches, 2nd ed, Sage, Thousand Oaks, CA.

Creswell, J.W. (2014), Research Design: Qualitative, Quantitative, and Mixed Methods Approaches, 4th ed, Sage, Thousand Oaks, CA.

Day, D.V., Gronn, P. and Salas, E. (2004), "Leadership capacity in teams”, The Leadership Quarterly, Vol. 15 No. 6, pp. 857-880.

D'Innocenzo, L., Mathieu, J.E. and Kukenberger, M.R. (2016), "A meta-analysis of different forms of shared leadership-team performance relations", Journal of Management, Vol. 42 No. 7, pp. 1964-1991.

Drath, W.H., (1998), "Approaching the future of leadership development”, McCauley, C.D., Moxley, D. and Velsor, E.V. (Eds), The Center for Creative Leadership Handbook of Leadership Development, Jossey-Bass, San Francisco, pp. 403-432.

Drucker, P. (2001), "The next society", The Economist, available at: www.economist.com/special-report/ 2001/11/03/the-next-society (accessed 15 April 2020).

Ensley, M.D., Hmielski, K.M. and Pearce, C.L. (2006), "The importance of vertical and shared leadership within new venture top management teams: implications for the performance of startups", The Leadership Quarterly, Vol. 17 No. 3, pp. 217-231.

Follett, M.P. (1924), “Creative experience”, Longmans Green, New York, NY.

Friedrich, T.L., Vessey, W.B., Schuelke, M.J., Ruark, G.A. and Mumford, M.D. (2009), “A framework for understanding collective leadership: the selective utilization of leader and team expertise within networks", The Leadership Quarterly, Vol. 20 No. 6, pp. 933-958.

Gibb, C.A. (1954), "Leadership”, in Lindzey, G. (Ed.), Handbook of Social Psychology, Addison-Wesley, MA, pp. 877-917.

Gioia, D.A., Corley, K.G. and Hamilton, A.L. (2013), "Seeking qualitative rigor in inductive research: notes on the gioia methodology”, Organizational Research Methods, Vol. 16 No. 1, pp. 15-31. 
Gioia, D.A., Thomas, J.B., Clark, S.M. and Chittipeddi, K. (1994), "Symbolism and strategic change in academia: the dynamics of sensemaking and influence", Organization Science, Vol. 5 No. 3, pp. 363-383.

Glaser, B.G., Strauss, A.L. and Strutzel, E. (1968), "The discovery of grounded theory: strategies for qualitative research", Nursing Research, Vol. 17 No. 4, p. 364.

Hatch, J.A. (2002), Doing Qualitative Research in Education Settings, SUNY Press, New York, NY.

Hiller, N.J., Day, D.V. and Vance, R.J. (2006), "Collective enactment of leadership roles and effectiveness. A field study", The Leadership Quarterly, Vol. 17 No. 4, pp. 387-397.

Hoch, J.E. and Kozlowski, S.J. (2014), "Leading virtual teams: Hierarchical leadership, structural supports and shared team leadership”, Journal of Applied Psychology, Vol. 99 No. 3, pp. 390-403.

Howe, N. and Strauss, W. (2003), Millennials Go to College: Strategies for a New Generation on Campus: Recruiting and Admissions, Campus Life, and the Classroom, American Association of Collegiate Registrars and Admissions Officers, Washington, DC.

Johansen, B. and Voto, A. (2014), "Leadership skills to thrive in the future", People and Strategy, Vol. 36 No. 4, pp. 4-6.

Kennedy, R.L. (2017), "Shared leadership in a matrix organization: an exploratory study", Doctoral dissertation, Fielding Graduate University.

Kocolowski, M. (2010), "Shared leadership: is it time for a change?", Emerging Leadership Journeys, Vol. 3 No. 1, pp. 22-32.

Kozlowski, S.W.J. and Bell, B.S. (2003), "Work groups and teams in organizations", in W.C. Borman, D.R. Ilgen and R.J. Klimoski (Eds), Comprehensive Handbook of Psychology, Industrial and organizational psychology, John Wiley and Sons, New York, NY, Vol. 12, pp. 333-375.

Lindsay, D.R., Day, D.V. and Halpin, M.S. (2011), "Shared leadership in the military: reality, possibility, or pipedream?”, Military Psychology, Vol. 23 No. 5, pp. 528-549. 0.5,

Mathieu, J., Maynard, M.T., Rapp, T. and Gilson, L. (2008), "Team effectiveness 1997-2007: a review of recent advancements and a glimpse into the future", Journal of Management, Vol. 34 No. 3, pp. 410-476.

Mathieu, J.E., Tannenbaum, S.I., Donsbach, J.S. and Alliger, G.M. (2014), “A review and integration of team composition models: moving toward a dynamic and temporal framework", Journal of Management, Vol. 40 No. 1, pp. 130-160.

Merriam, S.B. and Grenier, R.S. (Eds). (2019), Qualitative Research in Practice: Examples for Discussion and Analysis, Jossey-Bass, San Francisco, CA.

Merriam, S.B. and Tisdell, E.J. (2015), Qualitative Research: A Guide to Design and Implementation, Jossey-Bass, San Francisco, CA.

Morgeson, F.P., DeRue, D.S. and Karam, E.P. (2010), "Leadership in teams: a functional approach to understanding leadership structures and processes", Journal of Management, Vol. 36 No. 1, pp. 5-39.

Muethel, M., Gehrlein, S. and Hoegl, M. (2012), "Socio-demographic factors and shared leadership behaviors in dispersed teams: Implications for human resource management", Human Resource Management, Vol. 51 No. 4, pp. 525-548.

Müller, E., Pintor, S. and Wegge, J. (2018), "Shared leadership effectiveness: perceived task complexity as moderator”, An International Journal, Vol. 24 Nos 5/6, pp. 298-315.

Nicolaides, V.C., LaPort, K.A., Chen, T.R., Tomassetti, A.J., Weis, E.J., Zaccaro, S.J. and Cortina, J.M. (2014), "The shared leadership of teams: a meta-analysis of proximal, distal and moderating relationships", The Leadership Quarterly, Vol. 25 No. 5, pp. 923-942. 
Osborn, R.N. and Hunt, J.G. (2007), "Leadership and the choice of order: complexity and hierarchical perspectives near the edge of chaos", The Leadership Quarterly, Vol. 18 No. 4, pp. 319-340.

Pearce, C.L. (2004), "The future of leadership: combining vertical and shared leadership to transform knowledge work", Academy of Management Executive, Vol. 18 No. 1, pp. 47-57.

Pearce, C.L. and Conger, J.A. (2003), Shared Leadership: Reframing the Hows and Whys of Leadership, Sage, Thousand Oaks, CA.

Pearce, C.L., Conger, J.A. and Locke, E.A. (2008), "Shared leadership theory", The Leadership Quarterly, Vol. 19 No. 5, pp. 622-628.

Pearce, C.L., Hoch, J.E., Jeppesen, H.J. and Wegge, J. (2009a), "New forms of management: shared and distributed leadership in organizations. A special issue of journal of personnel psychology”, European Journal of Psychological Assessment, Vol. 25 No. 4, pp. 285-286.

Pearce, C.L., Manz, C.C. and Sims, H.P. (2009b), "Where do we go from here? Is shared leadership the key to team success?”, Organizational Dynamics, Vol. 38 No. 3, pp. 234-238.

Pearce, C.L., Manz, C.C. and Sims, H.P. (2014), Share, Don't Take the Lead, IAP, Charlotte, NC.

Pearce, C.L. and Sims, H.P. Jr, (2002), "Vertical versus shared leadership as predictors of the effectiveness of change management teams: an examination of aversive, directive, transactional, transformational, and empowering leader behaviors", Group Dynamics: Theory, Research, and Practice, Vol. 6 No. 2, pp. 172-197.

Pearce, C.L., Wood, B.G. and Wassenaar, C.L. (2018), "The future of leadership in public universities: is shared leadership the answer?", Public Administration Review, Vol. 78 No. 4, pp. 640-644.

Ramthun, A.J. and Matkin, G.S. (2014), "Leading dangerously: a case study of military teams and shared leadership in dangerous environments", Journal of Leadership and Organizational Studies, Vol. 21 No. 3, pp. 244-256.

Shondrick, S.J., Dinh, J.E. and Lord, R.G. (2010), "Developments in implicit leadership theory and cognitive science: applications to improving measurement and understanding alternatives to hierarchical leadership”, The Leadership Quarterly, Vol. 21 No. 6, pp. 959-978.

Sun-Tzu and Clausewitz, K.V. (2000), The Book of War: Sun-Tzu's "the Art of War" and Karl Von Clausewitz's "on War", Modern Library, New York, NY.

Sweeney, A., Clarke, N. and Higgs, M. (2019), "Shared leadership in commercial organizations: a systematic review of definitions, theoretical frameworks and organizational outcomes", International Journal of Management Reviews, Vol. 21 No. 1, pp. 115-136.

Uhl-Bien, M. and Arena, M. (2018), "Leadership for organizational adaptability: a theoretical synthesis and integrative framework", The Leadership Quarterly, Vol. 29 No. 1, pp. 89-104.

Wang, D., Waldman, D.A. and Zhang, Z. (2014), "A meta-analysis of shared leadership and team effectiveness”, Journal of Applied Psychology, Vol. 99 No. 2, pp. 181-198.

White, R.D. (1999), "Managing the diverse organization: the imperative for a new multicultural paradigm", Public Administration and Management: An Interactive Journal, Vol. 4 No. 4, pp. 469-493.

Wu, Q., Cormican, K. and Chen, G. (2020), "A meta-analysis of shared leadership: antecedents, consequences, and moderators”, Journal of Leadership and Organizational Studies, Vol. 27 No. 1, pp. 49-64.

Yukl, G. (2013), Leadership in Organizations, 8th ed., Prentice-Hall, NJ.

Zhu, J., Liao, Z., Yam, K.C. and Johnson, R.E. (2018), "Shared leadership: a state-of-the-art review and future research agenda”, Journal of Organizational Behavior, Vol. 39 No. 7, pp. 834-852. 


\section{Further reading}

DeChurch, L.A. and Mesmer-Magnus, J.R. (2010), "The cognitive underpinnings of effective teamwork: a meta-analysis", Journal of Applied Psychology, Vol. 95 No. 1, pp. 32-53.

Grille, A. and Kauffeld, S. (2015), "Development and preliminary validation of the shared professional leadership inventory for teams (SPLIT)", Psychology, Vol. 6 No. 1, pp. 75-92.

Gronn, P. (2002), "Distributed leadership as a unit of analysis", The Leadership Quarterly, Vol. 13 No. 4, pp. $423-451$.

\section{Corresponding author}

Sultan Serkan Cakiroglu can be contacted at: serkan_sultan_cakiroglu@iscte-iul.pt

For instructions on how to order reprints of this article, please visit our website: www.emeraldgrouppublishing.com/licensing/reprints.htm

Or contact us for further details: permissions@emeraldinsight.com 